Fronteiras: Revista de História

Metodismo (Justus Nelson), Igreja Católica e República: discursos, casamentos e família (Belém-PA, 1890) Ipojucan Dias Campos

\title{
METODISMO (JUSTUS NELSON), IGREJA CATÓLICA E REPÚBLICA: DISCURSOS, CASAMENTO E FAMÍLIA (BELÉM-PA, 1890)
}

\author{
Ipojucan Dias Campos ${ }^{1}$
}

\begin{abstract}
Resumo: $O$ artigo possui como princípio elementar firmar posição na lógica de que, em Belém-PA, o pastor metodista Justus Nelson, a Igreja Católica e a República jamais se distanciaram de concepções político-religiosas quando o eixo versava a respeito do casamento e família. Quanto a importância destes, aqueles pensavam a sua constituição como essenciais à sociedade, no entanto, fabricavam discursos dessemelhantes quanto a forma da celebração do ato solene a constituir linhagem dita salubre. Assim sendo, se por um lado, metodistas e República passaram a elaborar discursos no sentido de convencer que a união civil era legal e válida, por outro, a Igreja propagandeava o ato civil como espúrio por inexistir Deus em sua efetivação e, por esta razão, somente a sua celebração era prudente moral e religiosamente.
\end{abstract}

Palavras-chave: Metodismo (Justus Nelson); Igreja Católica; República; casamento e família.

\section{METHODISM (JUSTUS NELSON), CATHOLIC CHURCH AND REPUBLIC: SPEECHES, MARRIAGE AND FAMILY (BELÉM-PA, 1890)}

\begin{abstract}
The article has as an elementary principle to establish a position in the logic that, in Belém-PA, Methodist pastor Justus Nelson, the Catholic Church and the Republic never distanced themselves from political-religious conceptions when the axis was about marriage and family. As to the importance of these, they thought of their formation as essential to society, however, they constituted speeches dissimilar as to the form of the celebration of the solemn act to constitute a so-called healthy lineage. Thus, if, on the one hand, Methodists and Republic began to make speeches in the sense of convincing that civil union was legal and valid, on the other hand, the Church signed the civil act as spurious because God did not exist in its effectiveness and, for this reason, only its celebration was prudently moral and religiously
\end{abstract}

Keywords: Methodism (Justus Nelson); Catholic Church; Republic; marriage and Family.

\section{METODISMO (JUSTUS NELSON), IGLESIA CATÓLICA Y REPÚBLICA: DISCURSOS, MATRIMONIO Y FAMILIAS (BELÉM-PA, 1890)}

Resumen: El artículo tiene como principio firmar posición en la lógica de que, en Belém-PA, el pastor metodista Justus Nelson, la Iglesia Católica y la República jamás se distanciaron de concepciones político-religiosas cuando el eje versaba acerca del matrimonio y la familia. En cuanto a la importancia de estos, aquellos pensaban su constitución como esenciales a la sociedad, fabricaban discursos semejantes en cuanto a la forma de la celebración del acto solemne a constituir linaje dicha salubre. Así pues, si por un lado, metodistas y República pasaron a elaborar discursos en el sentido de convencer que la unión civil era legal y válida, por otro, la Iglesia propagaba el acto civil como espurio por no existir Dios en su efectivación y, por esta razón , sólo su celebración era prudente moral y religiosamente.

\footnotetext{
${ }^{1}$ Docente do Programa de Pós-Graduação em Ciências da Religião da Universidade do Estado do Pará (UEPA). Docente no Curso de História da Universidade Federal do Pará (UFPA). Doutor em História Social pela Pontifícia Universidade Católica de São Paulo (PUC/SP). E-mail: ipojucancampos@gmail.com
} 
Palabras clave: Metodismo (Justus Nelson); Iglesia Católica; República; matrimonio y familia.

\section{INTRODUÇÃO}

As interpretações a seguir firmam posição no argumento de que motivações políticoreligiosas nunca estiveram distantes de posicionamentos doutrinais (Igreja Católica e Metodismo, leia-se Justus Nelson) e igualmente da República, recém instaurada, quando o assunto era casamento e família. Por assim dizer, movimentos político-religiosos no âmago do casamento e da família é a sentença chave do presente artigo, ou seja, a preocupação é a de descortinar formas de entendimento arranjadas por Nelson, ${ }^{2}$ pelo Estado e pela Igreja Católica no que concerne a união entre homem e mulher na cidade de Belém-PA em 1890. Aqui é mister procurar explicar que o referido ano foi, por diversas razões, de suma importância à tríade ora à baila.

\section{Resumidamente:}

A República procurava tornar inequívoco à sociedade o Decreto-lei 181 de 24 de janeiro de 1890 que tornou o casamento civil o único válido no país, bem como a sua responsabilidade de separar cônjuges que não mais conseguissem se tolerar. No mesmo ano, contudo, através do Decreto 119 A, de 07 de janeiro de 1890, Estado e Igreja foram "separados" (Decreto 119 A, de 07 de janeiro de 1890. Governo Provisório da República dos Estados Unidos do Brasil de 1890). À Igreja Católica, a perda de parte de seu poder em virtude da institucionalização da lei do casamento cartorial obrigatório e da ruptura matrimonial, soava como afronta porquanto Deus estaria sendo expulso do lar brasileiro. (CAMPOS, 2016). Aos metodistas (leia-se Justus Nelson), as investidas do poder laico em searas secularmente dominadas pela Igreja tinham apenas uma função: a de transformar o Brasil em lugar civilizado, porque liberdade de culto era garantido a todos.

Nesta esteira, se deve afirmar que eles em nada divergiam quando pensavam o consórcio na qualidade de obra importante à sociedade, no entanto, colocavam-se em trincheiras opostas no que pertencia a forma de como as bodas deveriam ser celebradas, explica-se:

\footnotetext{
2 Justus Nelson foi um pastor metodista que pousou na Amazônia no final do século XIX. Fundou a Igreja Metodista Episcopal na cidade Belém, uma escola chamada Americano e o jornal "O Apologista Cristão Brasileira", principal meio de comunicação do missionário com a sociedade belenense.
} 
O metodista não as compreendia como sacramento. Inexistia, segundo sua leitura, passagem bíblica que conduzisse a esta classificação, ou seja, Jesus Cristo não teria se preocupado com tal assunto. Para o missionário casar era importante, entretanto, a união expressava significados bastante diferentes quando comparados ao desejado pelo Clero, por exemplo, "conseguiu" [tomando como base Mateus capítulo 19, versículos 8 e 9] justificar a viabilidade do divórcio, instituto repudiado pela Igreja.

A respeito:

A religião christã admitte o divorcio. A religião romana o nega na theoria. Jesus Christo deu por único motivo o adulterio. E elle intitula "adulterio" o casamento do culpado divorciado. Eis as palavras do Mestre Divino: Moysés, pela dureza dos vossos corações vos permittiu repudiar ás vossas mulheres; mas ao principio não foi assim. Eu vos declaro que todo aquelle que repudiar a sua mulher, se não é por causa de fornicação, e casar com outra comette adulterio; e o que se casar com a que outro repudiou, commette adulterio. (Matt. XIX. 8,9). (O Apologista Cristão Brasileiro. Belém, 01 de março de 1890, p. 02).

Não apenas no concernente ao divórcio, mas outros pontos foram de conflitos. Pelo exposto, este historiador compreende não ser possível ler o missionário dicotomizado entre o homem político e o religioso, ele em nenhum momento se apresentou desta forma, ou seja, ao dizer que segundo a Bíblia o divórcio era viável, o missionário apresentava o melhor que possuía da junção político-religiosa. Também outro ponto conflitante com a Igreja Católica se concentrava no tempo do casamento, para Nelson não importava o dia: finados, quaresma, dias santos.

\section{Casamentos na Quaresma}

Annunciamos a todos que nisso se interessarem, que para casamentos acatholicos não há impedimento de quaresma. Para nós não há um dia no anno em que não se possa casar. $\mathrm{O}$ impedimento que prohibe o casamento na quaresma não tem a mínima base na religião cristã. Portanto a todos que desejarem casar-se d'aqui até o fim da quaresma offerecemo-nos para os servir. (O Apologista Cristão Brasileiro. Belém, 22 de fevereiro de 1890, p. 02).

Doutrinalmente, nada colocava empecilho, dizia. Ao ampliar as probabilidades de tempo à celebração de enlaces, conseguia se aproximar de belenenses insatisfeitos religiosamente e, de forma paralela, "viabilizava" fiéis ao metodismo. De todo modo, havia uma aproximação deste com as determinações políticas, aqui classificadas como institucionais, porque este pastor estabeleceu "alianças" com o Estado republicano paraense a respeito de assuntos que lhe interessava como o da laicização do casamento. 
A Igreja Católica lia este assunto de maneira completamente distinta. Enquanto Nelson incontáveis vezes usou matrimônio e casamento como sinônimos, ela abrangia os termos diferentemente: matrimônio era a cerimônia religiosa, a união entre homem e mulher realizada por um ministro de Deus na sua casa (na igreja) e o casamento representava o ato civil conforme a legislação em vigor, consumado por meio das autoridades cartoriais. O civil era secundário, ato às margens do Criador e por isso pouco durava. A fabricação do discurso mostrava-se incisiva:

Nos paizes como o nosso onde se publicou o Concilio de Trento, o casamento civil é por sua natureza uma torpe mancebia ou um concubinato legal, e aquelles que, contentes só com o casamento civil vivem como marido e mulher, estão sujeitos ás penas impostas pela Igreja contra os concubinatos publicos. (Semana Religiosa do Pará. Belém, 23 de março de 1890, p. 182).

Por seu turno, o Estado desde 1890 dominava a celebração dita laicizada. Tal tomada de poder "satisfez" os metodistas sediados na cidade de Belém, entretanto, indignava os católicos, uma vez que o ato religioso - para efeitos civis - depois do Decreto 181 de 24 de janeiro de 1890 passou a inexistir no país. Repita-se que o casamento religioso perdeu o efeito civil que tinha, isto é, os casados somente na igreja de qualquer culto não poderiam dizer-se matrimoniados, porque a lei atrás citada determinou ser o civil o único capaz de legitimar as núpcias. (CAMPOS, 2004).

É mister afirmar que o argumento político-religioso possui um porto seguro de onde as interpretações em nenhum momento se desprenderam, qual seja: o da documentação. Metodologicamente este historiador vê o documento como matéria-prima principal no ofício de tentar compreender movimentos de indivíduos no seio de um tempo e lugar pretéritos e tentar ligá-los com os do presente. Por assim dizer, nada às fontes pode se sobrepor. Primeiro elas foram coletadas, depois interpretadas e, então, (longe de ser uma fórmula) chegou-se a compreensão de que o missionário, a Igreja e o Estado desenvolveram sofisticadas teias político-religiosas em torno do casamento e da família, onde sempre apresentaram cenários heterogêneos que marchavam em direção a conflitos sociais.

Pelo dito, o texto intitulado "Metodismo (Justus Nelson), Igreja Católica e República (Belém-PA, 1890)" foi apoiado nas seguintes fontes:

“Semana Religiosa do Pará” veículo de publicação semanal pertencente à Igreja Católica. Fazia oposição às mudanças que a República fazia na vida civil brasileira como a da institucionalização do divórcio e o do casamento cartorial. Para o semanário, as 
transformações pouco interessavam, pois que colocavam em xeque certezas políticas e religiosas do catolicismo.

“O Apologista Cristão Brasileiro", jornal protestante pertencente à Justus Nelson, pastor metodista, tinha publicação mensal. Para este, as mudanças que o regime republicano proporcionava na vida civil brasileira eram importantes, visto que iam de encontro às proposições da Igreja Católica, mas que também contemplavam necessidades clamadas por cidadãos de outros cultos. Neste sentido, o periódico apoiava política e religiosamente tanto o divórcio quanto o casamento civil.

“A República” era publicação diária que buscava sustentar a legalidade do regime como a defesa do Decreto-lei 181 de 24 de janeiro de 1890 que tornou laica a celebração do casamento civil e a decisão de se divorciar no Brasil.

Deste modo, nestas bases, seguem algumas ideias sobre a tríade em questão.

\section{REPÚBLICA $X$ JUSTUS NELSON $X$ IGREJA CATÓLICA: CASAMENTO E FAMÍLIA}

Justus Nelson, Igreja Católica e Estado, repita-se, compreendiam o casamento como a argamassa da coletividade, todavia, a respeito do seu preparo suas perspectivas nunca expressaram única composição. Este historiador ao notar que as três forças muito se interessavam pelo unir-se, porém ofereciam significados a ele diferentes, "não encontrou dificuldades" em observar que elas entravam em desinteligências diante do assunto.

Em conformidade com isso:

O casamento civil. A Semana Religiosa, como era de esperar, ataca ferozmente a nova lei do casamento civil. Na edição de domingo passado, o seu argumento principal basêa-se na premissa que o casamento é um sacramento. Para provar que é sacramento cita a autoridade de Pio IX. D'ella seguem umas conclusões, um pouco espantosas! Por exemplo: se sem o casamento só há um mero concubinato, e se antes de Jesus Christo não houve sacramento de matrimonio, então não se pode deixar de concluir que todas as uniões conjugaes antes de Jesus Christo eram o mero concubinato. Segue que a virgem Maria mesma, a "immaculada", era também filha do concubinato. Mas porque é que se cita o pio IX para provar que Jesus Christo elevou o matrimonio a dignidade de sacramento? Porque não se cita as palavras de Jesus Christo? Porque não nos dá as palavras do evangelho, em que este "sacramento" foi instituido? É porque na Bíblia inteira não existe uma só passagem de que se possa provar que o matrimonio seja sacramento? ( $\mathrm{O}$ Apologista Cristão Brasileiro. Belém, 15 de fevereiro de 1890, p. 01).

O Apologista Cristão Brasileiro (mais precisamente no que concerne às temáticas apresentadas: casamento, separação, família), "jamais" se colocou às margens da política- 
religiosa, ou seja, querelas com a Igreja Católica e, quando conveniente, com o Estado do Pará (e elas não foram poucas, por exemplo, aquando da institucionalização da prostituição por este) constituíram-se na base de sua linha editorial. Nesta esteira, as outras duas instituições (República e Igreja Católica) do mesmo modo se movimentavam no afã de estabelecer afinidades no meio em que estavam instaladas, dito de outra maneira, elas e, também Nelson, operacionalizavam probabilidades de sobrevivência no campo em disputa; aliás, os objetivos dos contendores basicamente eram esses.

Aproximações entre Justus Nelson e Estado existiram, porém quando convenientes.

O Apologista Christão que já tem tomado o gosto de dirigir uns desaforozinhos a quem o desagrada, não se contenta em fazer a propaganda de suas crenças, invectiva aos crentes do catholicismo. Não é assim que se ganha adeptos. Todos os cidadãos d`este paiz tem o direito de professar a religião que lhe approuver, sem que, por isso, mereçam censuras de quem quer que seja. (A República. Belém, 01 de abril de 1890, p. 02).

A arte de jogar não permitia amadorismos. O metodismo se retroalimentava do catolicismo, mas também através das leis "laicas". Essas são algumas características do poder do discurso no que diz respeito a sua mais banal constituição, elas (as características) tinham aspectos inter-relacionais os quais "nada" estava perdido a uma ou a outra formação discursiva. De tal modo, quando o Estado, com o nascimento da "liberdade" de culto religioso, mas também por meio do Decreto-lei 181 de 24 de janeiro de 1890 (as normas do casar-se e do separar-se), "iniciava" - "não mais do que isso" - uma tentativa de controle e, assim, buscava criar formatações em torno das pessoas, tais perspectivas pretendiam expressar espaços próprios que procuravam dar conta de suas especificidades. A República apresentava coletivamente uma "liberdade de culto" e na "mesma medida" a obrigatoriedade do casamento civil, estes mecanismos aspiravam representar comportamento ordenado e controlado das pessoas, isto é, o Estado mostrava a estas o quão era imperativo se submeter a dispositivos "laicos", os quais "faziam-se" superiores a qualquer outra determinação.

Os discursos se retroalimentavam, no entanto, isso em nenhum momento quis significar leituras e reproduções diretas do posicionamento de um e de outro, filtros existiam. Palavras e ideias ressignificavam-se conforme as conveniências daquele que se apropriava do discurso alheio, entretanto, é de bom alvitre reafirmar a seguinte lógica: para além de um servir de ponto de apoio aos outros e vice-versa é mister pensar que essas eram técnicas adaptadas ao específico de cada qual. Eis uma norma básica contida no pensamento dos contendores. O discurso esquadrinhava maneiras de pensar, e igualmente comportamentos e 
espaços onde esses discursos eram empregados; em conformidade com isso, os modelos de pensamento do Estado, da Igreja e dos metodistas podem ser vistos como técnicas que buscam localizar em um lugar hierarquias capazes de cumprir funções conforme as razões específicas que ele se propunha executar, mas também que dele se exigia.

Essas práticas informam os espaços que os três desempenhavam ou pretendiam desempenhar na sociedade que ajudavam a formar, na que estavam inseridos. Nunca agiram à revelia. Passos medidos e pensados com a finalidade de influenciar o alvo desejado, era tática basal. A se considerar que este alinhamento argumentativo tenha força, a tríade estudava separadamente o que as pessoas esperavam e depois atuava no interior destas perspectivas. $\mathrm{O}$ ponto nodal de Justus Nelson, Igreja Católica e República era o de influir indivíduos às suas causas. Ao se observar imaginários diferentes entre si em relação ao casamento é possível notar como eles se relacionavam com as pessoas e com o regime político vigente no último quarto do século XIX; assim sendo, a política era manobra próxima da religião e da religiosidade, elas não se excluíam, ao contrário, sempre estiveram juntas.

Era um jogo, e dos mais estratégicos. Estratégia quer dizer que as três forças atuantes possuíam poder de ascendência exercidas por meio de orientações explícitas e diretas às pessoas, ou melhor dito, ela (a estratégia) especifica o significado comumente aceito, qual seja: o de que existe uma forma de capacidade pela qual determinados indivíduos e instituições fazem outros indivíduos agirem de maneira diferente da estabelecida. Quer-se dizer que a Igreja Católica, Justus Nelson e o Estado influenciavam as pessoas a pensarem como eles pensavam e assim "cooptá-las” às suas causas. Nesta seara, quando o casamento civil foi colocado no patamar de lei, Justus Nelson bastante laureou tal ação política porque retirava do Clero a celebração, o que fez ampliar as margens de manobra de outros cultos diante da temática, o seu evidentemente estava incluído. Entretanto, a visão da Igreja Católica pode ser lida como absolutamente contrária, visto que compreendia ser a presença de Deus essencial na consumação das bodas, fato inexistente na celebração metodista e na cartorial, segundo ela.

O uso das entranhas político-religiosas jamais foi despropositado. Concernente a união legal entre um homem e uma mulher, Estado republicano e Nelson combatiam [nesta matéria e guardadas as devidas proporções] na mesma trincheira. Em conformidade com isso, sobravam julgamentos desfavoráveis à Igreja a envolver as uniões antes da institucionalização das bodas como sacramento, assim muitas certezas da Igreja Católica, como a união entre a "Virgem Maria" e José, entravam no eixo da crítica de seu mais ferrenho adversário. (O 
Apologista Cristão Brasileiro. Belém, 15 de fevereiro de 1890, p. 01). Mais e mais, aparecem os objetivos e finalidades das instituições em relação ao seu meio, porquanto se pensa que elas para alcançar seus afãs consideravam amplamente colocar em pauta, para não se perderem, as mudanças do tempo em que estavam inseridas. O tempo e o meio em que se vivia exerciam mediações nos objetivos de indivíduos e instituições e igualmente nas suas consecuções. Então, os escopos destes argumentos longe se encontram da liberdade das instituições em tela, ou seja, elas não atuavam de maneira independente em direção aos seus desígnios. Como se procurou explicar um pouco atrás, a trindade estava ligada de alguma ou de todas as maneiras à manifestação do Estado frente à laicização do casamento, assim tal atitude influenciava tanto apreensões da Igreja Católica quando as de Justus Nelson.

De tal monta, os movimentos de uma e de outra instituição na forma de fazer indivíduos agirem de determinada maneira era essencial às finalidades queridas, sendo que este percurso se pode aqui pensar como influência nas entranhas da política. Conforme o tempo, o lugar e as condições que estes apresentavam, alternativas eram fabricadas. Por assim dizer, os estudos político-religiosos de Justus Nelson, Igreja Católica e Estado na cidade de Belém expressavam variáveis profundamente complexas, tais como: um e outro atuavam nas frestas deixadas e/ou abertas da legislação, mas também nas doutrinas das instituições religiosas em questão.

Da tríade, os domínios políticos emanavam substancialmente. Semanários de propriedade metodista (de Justus Nelson), "O Apologista Cristão Brasileiro", o da Igreja Católica, "A Semana Religiosa”, e do mesmo modo diários que se posicionavam ao lado do Estado como "A República" expressavam pontos de vista de um tempo em que se firmavam jurisprudência à vida laica. Frente às matérias em pauta (casamento, sacramento do matrimônio, família, separação), as três instituições tinham a consciência de que o envolvimento para assegurar de alguma forma domínios de influência no bojo da sociedade era obrigatório. Elas lutavam por legitimidade no seio do coletivo, a qual se concentrava entre o casamento cartorial, para alguns o único a firmar legalmente à união dos gêneros, mas para outros não passava de amasiamento, e o matrimônio como sacramento. Esta busca e dependência da legitimidade em torno do discurso levou este historiador a tomar determinadas precauções; ela expressava para todos os envolvidos inevitável, conforme o prisma de cada um, autenticidade na medida em que o pensado como legítimo jamais perderia o paradigma de ser uma verdade, naturalmente tomando como base os ângulos individuais de cada um dos concorrentes. 
Esta longa duração político-religiosa ajustada na fala legitimadora, convidou a pensar que o central às três instituições era o de demonstrar à sociedade o papel e o lugar efetivo que cada uma desempenharia naquele presente. Na ótica de Justus Nelson, Igreja Católica e Estado era fundamental apresentar uma ordem prática disciplinar a respeito dos seus programas, porquanto perfeitamente sabiam que em certas épocas e meios o pensamento se ideologiza.

Pronunciava uma das partes:

É um dogma de fé, diz o santo padre Pio IX, que o Matrimonio foi elevado por nosso senhor Jesus Christo a dignidade de sacramento, e é ponto de doutrina, que o sacramento não é uma qualidade accidental, accrescentada ao contracto, mas que ele é da essencia mesma do matrimonio: de sorte que a união conjugal entre os christãos não é legitima senão no sacramento; fora do qual só há um mero concubinato (A Semana Religiosa. Belém, 10 de fevereiro de 1890, p. 01).

As questões impostas concernem a legitimização do discurso ideologizante desejados por cada um, assim sendo, a categoria dogma, matrimônio na condição de sacramento, concubinato e casamento civil eram assuntos base das instâncias ora em debate e dispunham de vieses definitivamente diferentes entre si. Todavia e com efeito, o "verdadeiro" se alojava em cada discurso, aliás aquele (o verdadeiro) deveria ser qualidade basilar deste (do discurso). Para este fragmento da história da cidade de Belém do final do século XIX, Nelson, catolicismo e República se esforçaram - cada um conforme o seu modo - em torná-lo racional àqueles a serem atingidos. Eles descortinavam, na medida em que suas concepções se tornassem ideologicamente sólidas, que a "civilização" e o "progresso" da coletividade sairiam vencedores, no entanto, individualmente estavam certos de que os dois substantivos somente apareceriam através da aplicação efetiva dos seus juízos.

Lucien Febvre, visceralmente advertiu: "O indivíduo é sempre o que lhe permitam que ele seja, tanto a sua época, quanto no seu meio social". (FEBVRE, 1978, p. 24). Elaborando "arranjos" destas investidas, dominar estes espaços (época e meio social) colocava-se como essencial à inserção das ideias de cada um no lugar de que faziam parte. Então, voltem-se aos substantivos "progresso" e "civilização". Eles deveriam apresentar-se firmes e vestidos e/ou transvestidos da lógica do discurso ideologizante coeso que impreterivelmente emanasse de mesma matriz, de mesma obra. Os poderes em questão desejavam penetrar no âmago da coletividade por meio de discursos previamente montados conforme o que pretendiam coletivamente comprovar. Basicamente, dessa maneira, os três 
operavam a própria vida e igualmente buscavam atuar na alheia, sendo que este agir concentrava-se na inoculação das suas ideias na sociedade.

Colocar à luz e compreender as condições de produção dos discursos de Justus Nelson, da Igreja Católica e do Estado torna-se qualidade sine qua non para se descortinar o quanto eles eram instrumentalizadores de poder. Nesta linha de raciocínio, Paul Zumthor, em texto seminal, espalhou: "todo discurso é ação, física e psiquicamente ativa. (ZUMTHOR, 1993, p. 75). O mesmo intelectual, entretanto, em outra reflexão exclamou ser o discurso forma poderosa de monumento. (ZUMTHOR, 1960, p. 06). À cidade de Belém, os contendores em questão desenvolveram ou procuraram desenvolver ideias, logo palavras absolutamente ancoradas na mentalidade não apenas na daqueles que produziam as narrativas, mas talvez e principalmente na dos seus destinatários. Com efeito, a geração de quadros político-religiosos com "forte" teor moral era ponto de vista elementar à tríade, posto que assuntos como sacramento do matrimônio, casamento civil, concubinato, família e "mesmo" o que teria dito Jesus, jamais - por eles - foram aproximados do banal, do superficialmente demonstrado.

Casamento Sacramento

O povo d'esta capital acaba de ver uma applicação pratica do sacramento do casamento. O "Diário do Gram Pará" de 13 do corrente noticia o fato da maneira seguinte:

"Casamento Catholico"

A policia fez casar ante hontem, á noute, na igreja de Sant'Anna, o individuo Gallo Francisco com Anna Sabina da Costa Teixeira, deflorada por esse individuo há dias passados. Serviram de padrinhos o subdelegado de Sant' Anna e o cidadão Francisco Ramos. Era realmente o caso de dizer, uma "imponente manifestação de fé". O subdelegado assim mostrava sua fé no sacramento para lustrar o crime, e o impôz. Agora segundo a doutrina da igreja romana a reparação está feita e o crime expiado. Mas o subdelegado deve saber que a parelha. Que ele assim conduziu para Sant'Anna ainda não é casada. Quanto a lei do paiz, cada um d'elles pode casar com qualquer outra pessoa que quiser. O acto que se celebrou na igreja de Sant'Anna não impede o casamento depois, nem de um nem de outro, nem lhes dá nenhum direito do matrimonio nem obrigação alguma um para com outro. E isso é o que o "Gram Pará chama casamento catholico". - A sobre e sem o mínimo valor, a não ser como um purgatoriosinho para tirar a mancha do crime. Mas podemos provar que nem segundo a lei eclesiástica são casados:

Um sacramento, segundo a doutrina da igreja romana, nada vale se faltar a vontade do sujeito. Nesse caso não é sacramento. O noivo foi casado a sobre e não por vontade própria: portanto não houve sacramento para elle. Segundo a lei eclesiástica, é nullo o casamento em que falta o consentimento de um dos nubentes, que é um dos requisitos indispensáveis para o casamento ser válido. 
Portanto não são casados nem perante o estado nem perante a igreja, as referidas vitimas do purgatório do subdelegado e do padre de Sant'Anna. (O Apologista Cristão Brasileiro. Belém, 21 de junho de 1890, p. 02).

O dito deveria ser convincente e neste meio estar atento e compreender o que os adversários diziam, era estratagema crucial. Estado, Igreja e Nelson se conheciam profundamente, sabiam das artimanhas e pretensões que um e outro articulavam ou pretendiam articular. Por vocação, neste diagrama, nenhum posicionamento localizava-se no domínio jogral, qualquer era errante; todos sabiam ou no mínimo estudavam os passos a serem dados, bem como os entendimentos dos demais. A apreciação dos movimentos era importante, todavia não chegava a ser a jogada magistral ou o xeque-mate na partida, o juízo do poder "real" da palavra não poderia ser visto somente por meio das certezas doutrinais, para uns, e das leis civis para o Estado. Se assim encerrada, a operação resultaria em erro final crasso e incontornável, então, o que se deve observar é que no seio das argumentações de todos que compunham esta tríade, jamais qualquer posicionamento se apartou das dos adversários. Quando Justus Nelson se dirigia à Igreja, suas observações nunca emanaram exclusivamente da doutrina metodista, por assim dizer, era mais um composto de visões que incluía "metodismo", "catolicismo" e laicismo.

Por esta compreensão, ao se referir a defloramento, casamento, matrimônio, Justus Nelson se apropriava das compreensões da Igreja Católica e das do Estado para se situar e, assim, formar representações valorativas em torno da sua missão na Amazônia. Esta noção de trabalho missionário não somente justificaria a necessidade de se andar sobre a doutrina, mas paralelamente se dava conotação conservadora a tudo que se concentrasse ao que seria casamento efetivamente válido no país. As palavras, as noções de Nelson e as compreensões da Igreja e do Estado, acerca dos temas em pauta, eram liquefeitas formando um dispositivo que apenas aparentemente era uno. O poder da palavra, da "ideia correta" se encontravam consignados na representação do discurso coerente. Concernente a isso, as três instâncias realizavam sobejos esforços no afã de se fazer convencer no seio de mudanças em curso como a da institucionalização do casamento civil e, nesta seara, cada um colocava suas reservas ou certezas atribuindo ao seu discurso a validade do que era dito.

Inexistia família sem casamento, todos (Nelson, Igreja e Estado) convergiam a esta fórmula. Todavia, o que propelia esses atores era a compreensão distinta, que cada um tinha, de como a linhagem descortinada como legal deveria ser constituída não somente na cidade de Belém, mas no Brasil. Por assim dizer, o que entrava imediatamente em jogo era a interpretação da mensagem no "exato" momento da sua requisição pelos sujeitos a serem 
influenciados, em outros termos, tratava-se de algo mais do que uma simples narrativa entre emissor e receptor, enfim, deveria ser compreendida como o estabelecimento da "verdade inquestionável”, segundo a leitura dos grupos em tela. O "progresso", a “civilização", a "verdade" provinham, se estabeleciam ou se negavam o seu vigor, conforme a força contida na mensagem formulada pelo emissor, sendo que tudo isto se associava à maneira de como o receptor lia o próprio enunciado. Seja o enviado pelo Estado, seja o pensado por Nelson, seja a doutrina católica, tudo dependia das performances do construtor do discurso e do intérprete (destinatário) desse discurso.

Aos três campos de poder, a voz narrativa era apresentada, ao mesmo tempo, com o sentido de salvação e também com o escatológico. Para o Estado, com suas leis laicas, inexistia família compreendida como legal sem a celebração do casamento civil; à Igreja, o matrimônio era sacramental e o resultado dele, a família, era o cimento da coletividade, sendo que as núpcias celebradas por ela eram as únicas duradouras, findadas somente com a morte de um dos cônjuges; por seu turno, em virtude de conveniências político-religiosas, já assinaladas, Nelson, se aproximava das convenções do Estado, consolidando parte do seu programa missionário na repulsa do casamento enquanto sacramento.

Mas, nem sempre a "aproximação" entre pessoas e instituições quis expressar entendimento.

Novas grosserias do Sr. Justus Nelson

Julgávamos o corajoso pastor methodista emendado do seu antigo vezo de agredir grosseiramente ao povo no meio de que vive. $\mathrm{O}$ artigo corpus Christi da sua folha de hontem veio nos convencer do contrario. Referindo-se ao ilustre Sr. dr. Vice governador do estado escreve elle: "penoso é mencionar o facto que elle é atheu declarado: religião nenhuma elle acceita. Para elle tanto vale a religião de Mahomet como a do Deus Omnipotente. Quizeramos saber quem autorizou o Sr. Nelson a fazer tão audaciosa afirmação. Quando mesmo, porém, o Sr. dr. Vice-governador fosse Atheu, dizer-se que a seus olhos tanto vale o christianismo como o mahometismo ainda seria uma injuria a sua reconhecida ilustração e Sentimentos. É preciso que o senhor Nelson se acostume a tratar com mais consideração as pessoas. No mesmo artigo, mais adiante, diz o famigerado pastor: e os fieis? $\mathrm{O}$ que d'elles. É melhor não dizer demais a seu respeito; pois em geral não brilham pelo rigor da moral. A sua devoção não é a devoção à virtude; pois as virtudes n'elles e n'ellas muitas vezes... Deixamos esse assumpto aos que mais de perto conhecem. D'esta maneira, o Sr. Nelson lança insinuações deshonrosas, não somente a maioria da população, como também, o que é mais doloroso, até as famílias que por serem de crenças catholicas não teem por isso menos direito a serem respeitadas. O Sr. Nelson deve cohibir-se. Queremos ampla liberdade de culto, mas não de insultos. Alem de que, é digno de severa censura que; quando todos se empenham em promover a ordem, o respeito mutuo e a elevação do jornalismo, o Sr. Nelson esteja por 
sua imprudência a provocar desabafos e retaliações. (A República. Belém, 15 de julho de 1890, p. 01)

Parece ser redundante, mas alianças apenas se sustentam até quando convenientes. Entre Justus Nelson e a República há muito as relações faziam-se ora amistosas, ora tensas. Talvez apenas nos momentos anteriores e nos primeiros meses da Proclamação (quer-se dizer dias iniciais) estes campos tiveram alguma simpática ligação. Distanciamentos ocorreram porque o político-religioso em disputa muitas vezes se demonstrou em ferida onde remédio inexistia a se aplicar, então, se pode compreender porque os sujeitos (as instituições) tinham suportes representativos ligados a representações espaço-temporais "mensuráveis", os quais suas visões indicavam ao "progresso", à “civilização", ao "desenvolvimento".

A fabricação do discurso é uma ação do pensamento, nunca algo espontâneo. No que respeita a Justus Nelson, Igreja e Estado, ela (a fabricação) continuadamente esteve ligada a natureza e a cálculos bastantes difíceis; eis porque a grandeza de cada construção narrativa apenas é possível ser vista por aqueles que descortinam determinada projeção discursiva como verossímil. São os movimentos realizados pelos discursos em sociedade que elaboram certezas no interior de cada corpo tocado por ele; em conformidade com isso, pensa-se ser [neste instante] a seguinte alegoria bem adequada: se o cego consegue ver e ler o mundo com as mãos, com a sua bengala que a cada toque nos objetos os nervos da sua mão vibram e mandam informações para o seu cérebro, as propostas em pauta colocavam as coisas em patamares parecidos, isto é, cada discurso compreendia que a sociedade ou, ao menos parte dela, estava cega, mas que tinha a possibilidade de conhecer a "verdade" ao tocar as perspectivas de Justus Nelson ou as da Igreja Católica ou as do Estado; assim sendo, formouse o paralelo entre alguém que "nada" vê e uma sociedade que no final do século XIX pouco conseguia enxergar, conforme cada qual dos discursos.

O performático de cada um nunca, para ninguém (emissor e receptor), poderia ser visto na condição de sumário, jamais deveria ser descortinado na ordem do marginal. As três instituições base deste ensaio não se distanciaram em qualquer momento de pelo menos dois dos inúmeros referenciais elementares que balizaram as rinhas em que se envolveram, quais sejam: a viabilidade prática dos seus discursos político-religiosos e a certeza de que as mensagens seriam compreendidas pelos seus destinatários. Estes eram campos onde as oposições se encontravam sem escapatória, porquanto se tratava de universo de sentido que se constituiu na cidade de Belém a partir do momento em que o Estado, a Igreja e Justus Nelson perceberam a precisão de se colocarem mais ativamente diante dos seus desejos. 


\begin{abstract}
Sobre casamentos
A pena de seis mezes de prisão imposta ao ministro de qualquer religiao que celebrar casamentos antes do casamento civil é uma pena justa e que já se tornava clamorosamente necessária. Na França os ministros de qualquer religião, são obrigados a não casar ninguem, antes do casamento civil. A infracção voluntaria ou proposital d'este preceito, é punida, não com seis mezes de prisão, simples, mas, sim, com dez annos de galés. O governo provisorio foi mais generoso, foi, diremos melhor, mais liberal: concedeu que os nubentes casasem-se indifferentemente primeiro na egreja que no tribunal civil. Muitos casaram-se segundo os ritos de sua religião e não cumpriram a lei, comparecendo ao juizo civil. Mas o governo não devia consentir que o futuro dos filhos, a legalidade das heranças, ficassem sacrificados pelo fanatismo dos paes mal aconselhados. Hoje gritam que foi um attentado a liberdade de consciencia. Mas, por Deus, também não era um attentado identico, concitar o povo a desrespeitar a lei, ensinando erradamente, falsamente, que só o casamento religioso era verdadeiro. (A República. Belém, 01 de julho de 1890, p. 01).
\end{abstract}

A coerência de um discurso está diretamente ligada a forma de como o mesmo é fabricado, mas também recepcionado. Longe da redundância, o seu papel é o do convencimento dos outros por meio de ideias. Ocorriam, na medida em que o "adversário" avançava, refinamentos na aparelhagem da escrita; este aprimoramento quer/pode significar diversidade de domínios, tais como promessas de prisão por existirem leis laicas superiores a quaisquer outras, críticas a essa probabilidade como apoios a elas e também expor que apenas nos interstícios do matrimônio Deus se fazia presente e por isso orientar para que ninguém se casasse no civil, se encontrava na esteira do comum, por fim, a montagem da maquinaria político-religiosa, pelos três competidores, era bastante sofisticada. A se considerar o exame em tela, diversas perspectivas abrem-se no que respeita ao modelo do consórcio, a moralização desejada a ser seguida pelas pessoas, visto que em tempo nenhum se deve perder de vista a compreensão de que as forças contendoras entendiam que o que estava em jogo era a formatação do indivíduo como ser descritível, analisável.

A leitura que cada um organizava dos seus posicionamentos possuía escalas de gradação, as quais mudavam conforme as necessidades do espaço e do tempo histórico. Estes deveriam se enquadrar "objetivamente" às lógicas de "progresso" e "civilização" o que impossibilitava postura totalmente intransigente diante de assuntos aflitivos como casamento, civil, matrimônio, família. De qualquer modo, o objetivo político-religioso de Nelson, Igreja Católica e República era o de acomodar seus princípios em argumentos teóricos que pudessem ser compreendidos por todos que tivessem contato com suas concepções. Além disso, estes emissores buscavam convencer seus destinatários no seio de sistemas próprios de opressão, coerção e ameaça, os quais - para tal propósito - não era raro o uso da Bíblia, de 
Jesus, de Deus, da Virgem Maria, da autoridade papal, da legislação laica, ou seja, obviamente, cada qual lançava mão das ferramentas e utensílios forjados e tinham à disposição, mas jamais construindo dispositivos disparatados entre o religioso e o político, aliás, estes não são descortinados nestas reflexões como meios separados, enfatize-se, e mesmo profundamente diferentes um do outro, eles interagiam formando inter-relações mútuas e inseparáveis a ponto de inexistir sentido, aos propósitos de Nelson, Estado e Igreja, se analisados separadamente.

Nestes encaminhamentos encontrou-se e analisou-se: "A pena de seis mezes de prisão imposta ao ministro de qualquer religião que celebrar casamentos antes do casamento civil é uma pena justa e que já se tornava clamorosamente necessária”. (A República. Belém, 01 de julho de 1890, p. 01). O argumento de ser o político-religioso aparelho de uso das três forças em disputa é absolutamente claro, visto que a República em virtude de a Igreja, no uso das suas forças orientar as pessoas a recusarem a união laica, porque se tratava de mero concubinato de onde Deus havia sido excluído por decreto civil, se posicionava incisivamente. (CAMPOS, 2016). O conceito de casamento não ocupava o mesmo espaço, nem mesmo possuía único significado, então, aqui, mora boa parte da problemática a envolver as três forças, visto que as querelas se desenrolavam no seio de quem construiria discurso mais coerente.

Quando cada uma das forças se mostrava desejosa de ser a autora da jogada magistral, o xeque-mate, cursos alternativos eram tomados e/ou forjados pelos personagens da história. Preferir um caminho e não outro era parte do jogo e, neste campo minado, para Nelson, Igreja e Estado inexistia a concepção de que os indivíduos não se encontravam livres a qualquer hora, isto é, disponíveis às investidas de um e de outro. A emergência de certo valor visto como coerente (nestas intervenções, o político-religioso de cada uma das três forças em questão) em determinado tempo e espaço deve ser explicada pelas ações realizadas, pelas pessoas no seio deste tempo e espaço, isto acontece porque história é movimento e tal movimento deve ser acompanhado por discursos que possam convencer os indivíduos que elaboram o tempo e o espaço em disputa.

Diante dos posicionamentos dos adversários, tudo se expressava por meio de diatribes. Frente ao casamento e à família, os contendores - cada qual à sua maneira descortinavam a infelicidade de alguns como evento melhor do que se a infelicidade fosse de todos, ou seja, o aparato político-religioso transparecia, igualmente, a eles como a carta principal do baralho, um coringa. Eis, vários aspectos salutares contidos nas falas dos 
querelantes. Exemplar neste sentido é que o "progresso", a "civilização" ligados ao tempo e ao espaço dependiam diretamente das escalas de medida manipuladas por aqueles observadores e isso colocava o discurso individual de cada um sempre como o mais sólido. Muito embora em nenhum ponto, nestes argumentos, se queira suprimir a possibilidade da introdução de inovações narrativas, é mister considerar que a natureza do pensamento deles, as modalidades do seu emprego não lhes permitiam substituir ou acrescentar fórmulas confessadamente radicais, porque dois dos três pensamentos estavam na linha doutrináriareligiosa (catolicismo e metodismo) e o outro ao menos mostrava-se propenso às leis laicas, muito embora nunca tenha se localizado equidistante de aspectos religiosos. Entrementes, por este motivo, porém não apenas por este motivo, a Igreja Católica, o Estado e o Metodismo tinham em suas linguagens fluidez e também caráter "definitivo" nos discursos, os quais eram recitados em público para dar conta de certas demandas como as do casamento e as da família, demasiadamente em pauta no final do século XIX e início do XX.

Quando imprescindíveis, alocuções político-religiosas eram aproximadas.

Como pastor da igreja methodista episcopal perguntam-nos se continuamos a casar. Respondemos que sim: mas, sempre com certas explicações. Dizemos sempre que é valido o casamento civil, sem outra formalidade alguma: que mesmo perante Deus são perfeitamente casados os nubentes que só se aproveitam do casamento civil. (O Apologista Cristão Brasileiro. Belém, 24 de maio de 1890, p. 02.)

O estudo do estilo do discurso é fascinante. É como se o elaborado por cada uma das forças em disputa - de pronto - pudesse responder e convencer um grupo, satisfazer uma expectativa, preencher uma necessidade que o destinatário requer. O discurso é "sempre" emitido como uma necessidade da coletividade por respostas ou como se a sociedade precisasse ouvir respostas. A coletânea de argumentos deveria sair do emissor aos destinatários na condição de coerentes proposições, ou seja, com eloquência particular onde palavras e frases tivessem fluência e facilmente fossem compreendidas. O discurso montavase para persuadir; assim, conforme o ponto de vista de cada um, o uso de Deus, de Jesus, de Maria Imaculada, do casamento civil, do matrimônio, da família era o meio para realizá-lo e para que não ficasse na faculdade de modelo desiderativo. Eis por que a tríade mantinha lutas renhidas; para além disso, ao se analisar amiudadamente os três ângulos de altercação, "nenhum" dos contendores sediados na cidade de Belém estava disposto a se apresentar à coletividade através de contornos frouxos ou por meio de modelos imperfeitos. 
O aspecto central deste texto, lembra-se, é o de que havia elos inquebrantáveis entre o político-religioso no seio das análises de Justus Nelson, Igreja Católica e Estado quando expunham seus vislumbres a respeito do casamento e da família. Nestas tramas a respeito do discurso, como George Lefebvre (1971) bem disse, um dos objetivos da historiografia não é o de perseguir uma narrativa real, mas sim o de oferecer interpretações aceitáveis aos processos históricos. Evidentemente este é um dos princípios do presente texto, contudo, imprudente seria não reafirmar que as forças em luta, dessa maneira, não viam os seus procedimentos, ou seja, suas construções narrativas eram reais e deveriam ser seguidas pela sociedade. Todos trabalhavam em torno da difusão da ideia e, adverte-se, que para tal empreitada ninguém se inseriu amadoramente, os periódicos "A Semana Religiosa do Pará”, "O Apologista Cristão Brasileiro" e "A República", que o digam. Em nenhum tempo se pode negar o discurso enquanto ferramenta poderosa, principalmente quando se compreende a forma como ele foi fabricado. As narrativas dos três contendores procuravam (repita-se: cada um ao seu estilo) atualizar, englobar e reproduzir o compreendido como essencial ao todo. $O$ que os destinatários liam situava-se, por assim dizer, no resultado de genealogias do discurso profundamente preparados ao longo do tempo.

"Progresso", "civilização", casamento, família foram categorias encontradas na produção dos discursos em tela. Porém, não se deve deixar às margens que Justus Nelson, Igreja Católica e Estado construíram interpretações sem perder o direcionamento do frescor das suas "certezas" doutrinárias e laicas, isto acontecia [acredita-se] não propriamente em decorrência de uma evidente intenção, mas principalmente e talvez unicamente em virtude da fiúza que cada um detinha na certeza da unicidade [aqui se quer escrever verdade] das suas ações diante dos leitores. Claramente não negligenciavam o que entendiam ser o poder "real" contido na palavra, porquanto ao lançarem mão da mentalidade buscavam elaborar quadros gerais do visto na condição de moral. Nestas condições, se instalava um aspecto angular, qual seja: a riqueza das traduções que diziam respeito como o outro deveria agir. De modo particular cada antagonista abrangia a sua voz na qualidade de um artesão que modelava/fabricava o objeto/bem que seria usado pela sociedade em um dado tempo e espaço carecedores de "civilização" e "progresso", da "verdade" e "salvação".

Jogava-se, sendo que neste jogo o produzido jamais poderia ser ordinário ou superficialmente demonstrado, as palavras da narrativa deveriam ter força e toque de convencimento [conforme o ângulo do receptor, logicamente], então, o discurso prudentemente fabricado possuía investidas enriquecedoras, as quais se firmavam no bojo do 
Fronteiras: Revista de História

Metodismo (Justus Nelson), Igreja Católica e República: discursos, casamentos e família (Belém-PA, 1890) Ipojucan Dias Campos

seu próprio fundo argumentativo. Mas, ao entrar em contato com múltiplas características dos pontos de vista [discursos] veio à baila a certeza de que um se nutria do outro para sobreviver, para se construir na cidade de Belém de 1890; por assim dizer, as dinâmicas pensadas através deste viés acoplavam-se a subordinações mútuas concernentes ao pensamento de cada um dos contendores, todavia, é claro, na especificidade, os três possuíam substratos mentais próprios. O modelo adequado de união e consequentemente de família a ser seguido estava em jogo; nesta esteira, a performance dos jogadores dependia dos desdobramentos dos atos gerados pela intenção própria de cada um. Com efeito, a narrativa em torno do que se desejava comprovar como mais "civilizado" deveria criar um acontecimento nos interstícios da vida do receptor, assim sendo, os contornos, o espetáculo e o medo quanto às bodas e à família demonstravam-se na condição de uma presença amiga, mas igualmente ameaçadora aos que eram "convencidos" por um ou outro discurso.

No dia 9 do mez findo, na casa de residencia do redactor d'esta folha foram casados pelo cidadão juiz de direito, Dr Geraldo Paez de Andrade, o Sr Fillipe Tercilio de Brito e exma. Sra. Maria Melania Valmar, membros da igreja Methodista episcopal d'esta capital. Foram testemunha do acto solene o Sr. Justus H. Nelson e sua exma esposa, D. Francisca B. Nelson. Em seguida, tambem com assistencia do symphatico dr. Juiz, e muitos amigos, o pastor da igreja rogou a bênção de Deus sobre a união matrimonial que se acabava de celebrar. (O Apologista Christão Brasileiro. Belém, 01 de outubro de 1892 , p. 02).

Os componentes usavam as armas que tinham, no entanto não se furtavam de forjar outras julgadas mais refinadas. Desde 26 de junho de 1890, por ocasião do Artigo $2^{\circ}$ do Decreto 318, a República tornou obrigatório primeiro o ato civil e depois, caso fosse de interesse dos agora casados, a solenidade religiosa poderia ser consumada. A respeito, determinava a República: "O ministro de qualquer confissão, que celebrar as cerimonias religiosas do casamento antes do acto civil, sera punido com seis meses de prisão e multa correspondente á metade do tempo". (Decretos do Governo Provisório da República dos Estados Unidos do Brasil de 1890). O determinado pelo Estado fazia aproximar ou distanciar as instituições; não que somente a partir do dito por ele todas as ações metodista ou católica procedessem, mas também nada dispensa levar tal princípio em conta. Isso é explicado em virtude de existir forte nexo entre as performances das propostas, ou seja, o comportamento de um influenciava fortemente o proceder dos demais, sendo que tal movimento era próprio do tempo e espaço vivenciados por Justus Nelson, Igreja Católica e Estado. 
Todos desejavam ter o monopólio da palavra verídica; os discursos apresentados no seio da cidade de Belém queriam intervir sempre na condição de poder e verdade. Ante este princípio, o sopro imperativo aparecia transvestido em variadas ocasiões do sacramental/doutrinal às leis laicas, entretanto, ela (a imposição de cada qual dos contendores) pode ser vislumbrada não somente como transmissão de saberes, mas essencialmente na faculdade de uma doutrina na qual se encontravam posturas lógicas e inquebrantáveis. Nestas lutas havia a procissão de três mensagens díspares, mas que se retroalimentavam. Ao contrário do pensamento mais objetivo, as propostas em tela de alguma ou de todas as formas se uniam, de alguma ou de todas as formas se ligavam por elos de dependência, onde o proceder de cada qual influenciava de maneira inequívoca a maneira de pensar e de agir do outro. Porém, nenhum duvidava da ideia de que o discurso bem elaborado, sofisticado, organizado e enriquecido pelo seu próprio conteúdo não era detentor de poder, ou seja, se as palavras estivessem firmadas em bases sólidas um quadro moral equidistante do ordinário seria formatado.

O culto do político-religioso pulsava nos domínios mais profundos, tal constatação permite afirmar que as forças querelantes culminavam no distanciamento do discurso banal. Este deveria ser consignado a palavras fortificadas.

Portanto, não se lhes pode administrar os sacramentos, nem se lhes pode conceber as honras de sepultura ecclesiastica, se morrem sem signaes de arrependimento. A Igreja considerará illegítimos os filhos que nascem d’esses casamentos puramente civis, e Deus condemnará ao inferno seus paes concubinarios, se não arrependerem com tempo, e se não se separarem ou contrahirem matrimonio na presença do paracho e de suas testemunhas. (Semana Religiosa do Pará. Belém, 23 de março de 1890, p. 182).

Cada qual apresentava suas certezas. Mas, o que estava e o que não estava sob o poder dos discursos manifestados? Crê-se que "apenas" a sua fabricação pode-se dizer controlada, todavia não o desejo do seu sucesso nas vontades dos indivíduos. Com efeito, ligado a esta concepção há um axioma: dificuldades latentes de Justus Nelson, do Estado e da Igreja Católica de compreender que havia objetivos que dependiam estritamente deles (por exemplo o da produção dos discursos), mas diversos dependiam de modo algum (como a predominância das suas certezas no bojo da coletividade). Isso não estava no raio do poder deles, posto que o casamento e a família jamais dependeram [ao menos estritamente] da fabricação de discursos, eles sempre se ligaram às negociações tramadas no cotidiano. Jamais se deve pensar no definitivo, aliás nada aqui o sustém, porque as pessoas formadoras das 
instituições (casamento e família) não podem ser pensadas, em nenhum tempo, como satisfatoriamente doutrinadas e a este respeito é de bom alvitre expressar que ninguém estava/está suficientemente doutrinado diante de qualquer dimensão da vida.

Neste patamar teórico, o agente político-religioso encrustado na tríade enfrentava dois poderes incisivamente fortes: a fabricação narrativa seguia obrigatoriamente regras para se demonstrar coerente em si mesma, em seu interior; e as contingências externas, quer-se dizer: as condições impostas pelas pessoas a serem atingidas pelas montagens dos discursos foi domínio movediço ao acesso. Entre esses espaços, o imponderável se fazia presente, no entanto quase sempre ignorado pelos querelantes. Nesta seara, múltiplos combates naquilo em que Justus Nelson compreendeu como "liberdade", o Estado como "institucionalização do poder laico" e a Igreja Católica, com faculdades avessas aos dois, dizia ser a "violência à fé e à sociedade brasileiras", foram travados. A elaboração do político-religioso era uma engenharia e como dele partia o discurso, este passava a representar - ao seu respectivo constituidor - a "civilização", o "progresso", a "coerência" e a "ética", "reais" às pessoas.

Fabricar discursos e lançá-los na sociedade nunca se consubstanciou na perfeição. Eles sempre enfrentaram contingências formuladas pelos receptores. Ora, então, ao corpo social inexistia razão suficientemente forte que se exprimisse através de palavras totais, que fossem vislumbradas como as únicas a serem seguidas. Por assim dizer, ao menos em "um ponto", houve convergência entre a tríade: a certeza da presença de uma miopia por parte de quem lia as mensagens, porquanto cada um [da sua forma] descortinava a sua narrativa como a portadora do acesso ao real, da verdade e da constituição da racionalidade em torno do casamento e da família e por isso não deveria ocorrer dúvidas em torno das bases da verdade. As apresentações não descuidavam do hiperbólico, por isso, entretanto, não apenas por isso, esqueciam da probabilidade de que os leitores (as pessoas) eram absolutamente voltados para o possível, porém os próprios discursos indispunham de capacidade de ver que o realizado por eles não passava de representações simbólicas de dadas interpretações acerca do que se desejava tornar total à coletividade. A narrativa da purificação, do enunciado como apropriado era forte pois quem o propunha tratava-se de autoridade constituída e essa qualidade se transfigurava em precisão a quem a "narrativa verdadeira" era proposta.

No bojo dessas características, convencer por meio do discurso expressava "somente" o que as pessoas não podiam admitir como "verdadeiro". Aliás, esse ponto era nevrálgico porque nele se davam as condições necessárias à produção das "verdades" e concernente a esta assertiva é mister dizer que as três instâncias deflagradoras de tensões, 
sabiam disso. Nestes meandros [e as propostas das forças em disputa isso provam] nunca houve única forma de se construir a "verdade", mas obrigatoriamente diversas; nestes estudos, por exemplo, passeiam pelo menos três. Então, a priori, as do Estado, as da Igreja e as de Justus Nelson atentavam às condições de possibilidade à formação discursiva, posto que mesmo inexistindo algo que se possa dizer universal e assim chamá-lo de discurso unitário verdadeiro, eles jamais pensaram assim, visto que as suas determinações eram as "reais". No entanto, nesta seara, é de bom alvitre recomendar a interpretação de que tal lógica presente nos poderes em tela não os tolheram do movimento, ou seja, ao mesmo tempo em que descortinavam a existência de um discurso verdadeiro, este era modificado conforme as necessidades daqueles que o elaboravam, bem como conforme as dos receptores dele.

Nestas circunstâncias, as equivocações subsistentes "deixavam” de existir. Elas eram firmadas por meio de retóricas que impregnavam a forma de pensar do elaborador na mentalidade do destinatário. A "mensagem verdadeira" fabricava-se, é evidente. Era formada por artesãos de ideias e de palavras que possuíam a sensibilidade de perceber os predicados daqueles que haveriam de recebê-las através do ler e/ou do ouvir. Em relação a estas características, a fabricação do "verdadeiro discurso" jogava com elas, porque lançava nelas a sua aposta central, tanto que delas [em parte] dependiam o destino político-religioso da sociedade. Com efeito, mesmo reduzido ao seu emprego mais consagrado, ao status de convencimento, jamais se pode esquecer que os discursos são abalizados pelas influências difusas que os marcam ao longo de um tempo e de um espaço e que, paralelamente a tal concepção, se localizam aqueles que os produzem. Ou melhor dito: as entonações das palavras proferidas e os gestos executados no púlpito ou no lugar de legitimação das leis, deveriam louvar a adequação do campo designado, isto é, do lugar a ser atingido. Aqueles que buscavam forjar o discurso político-religioso "verdadeiro" concentrado no casamento, no matrimônio, na família necessariamente tinham de buscar estes paradigmas e lançá-los à coletividade.

\section{CONSIDERAÇÕES FINAIS}

$\mathrm{Na}$ genealogia dos arranjos dos discursos, nenhum deles caminhava de forma autônoma, todos se ligavam por meio de apropriações mútuas às ideias do adversário a ser vencido. Na narrativa, os conjuntos ora apresentados ao leitor se articulavam para perturbar as certezas do vizinho e, nestas circunstâncias, estratégia recorrente era a da assimilação do visto como coerente, mas também ignorar o compreendido na qualidade de inexpressivo. O Estado, 
a Igreja Católica e Justus Nelson - cada qual a sua maneira - compreendiam suas teses no viés de algo que detinha o poder de explicar porque a sociedade estava como estava, todavia, nesta linha, igualmente, descortinavam dispor de força para mudá-la, isto é, quando suas proposições se tornassem predominantes, a sociedade jamais permaneceria como antes.

Empreendedores, dúvidas não pairam. Inovadores, a segurança não se aplica de forma tão afirmativa. A sociedade em estudo mudava, como mudou em domínios pretéritos, e isto "explica" que as transformações predecessoras tornaram viáveis os enfrentamentos executados pela tríade naquele "presente". A formação político-religiosa mostrava-se dessa forma, ou seja, tratava-se de tornar possível um domínio até então fora do alcance, desconhecido. Era o alcance do saber da "verdade".

Igreja Católica, Estado e Justus Nelson mostravam-se como os centros das controvérsias a respeito do político-religioso existente no seio do casamento, da família e da separação. Aliás, controvérsias concentravam-se na base da distinção do pensamento deles e, neste sentido, ela pode ser caracterizada - para cada uma das leituras - na qualidade de agente ético encravado entre dois poderes fortemente "distintos": os dos discursos propostos e os da sociedade. Sobejamente interpretou-se que as narrativas de convencimento se retroalimentavam, porém, ao mesmo tempo, eram opostas. Isso se explica porque as necessidades as obrigavam a seguir regras históricas sobre as quais "não" poderiam modificar. Em conformidade com esta concepção, após se fortalecerem uma da outra e depois de contornarem esta contingência tudo as forçava em direções imprevisíveis, porquanto entraria em cena a coletividade ou os efeitos das narrativas na coletividade.

As narrativas político-religiosas seguiam diversas trilhas e uma delas era a de se exprimir pelas frestas dos posicionamentos alheios, isto é, através da "perda" de referenciais ditos clássicos do outro. Neste patamar, não se pode esquecer que a universalidade e a inteligibilidade do real encontravam-se no seio de cada discurso e destes combates ergueu-se aquilo que Nelson, Igreja e Estado chamaram - cada qual ao seu modo - de verdade imutável. Olhos político-religiosos e intelectuais profundamente treinados e disciplinados existiram para indicar os caminhos a serem seguidos por aqueles julgados desencaminhados, ou seja, evidentemente os discursos atuavam na desordem ou na aparente desordem de posicionamento dos outros, então, constatada a fragilidade se formaria uma ordem necessária e inteligível ao conjunto da sociedade, segundo cada qual das narrativas apresentadas. Um desejava subverter o domínio do outro no cenário belenense. 
O político-religioso concernente às funções do casamento, da família e da separação podem ser caracterizados como instituições sociais, como sistemas de valores cuja a "pureza" do objeto lançado à sociedade nunca se poderia isolar, uma vez que os três discursos estão entrelaçados imoderadamente. Ao se considerar a montagem do discurso na faculdade de parte do social, as instituições não dispunham de força, sozinhas, nem de criá-lo e muito menos de colocá-lo em funcionamento; ele pode ser significado, na sua essência, na condição de contrato coletivo ao qual as pessoas deveriam se submeter para que a sociedade viesse a conhecer o "progresso", o "desenvolvimento" e a "civilização". Para que os discursos apresentados, ao menos em parte, se mostrassem vitoriosos haveriam de articular uma equação que ligasse o esforço coletivo da sua fabricação ao convencimento mínimo de grupos sociais. Nesta estrutura, a construção do político-religioso em torno do casamento, da família e da separação, no seu cerne, ocupava-se de si, entretanto, isso não expressava ou no mínimo não poderia expressar simples preocupação momentânea, mas inquietação que formava elos imoderados com a sobrevivência do próprio discurso elaborado. Ora, não foi isso o que Alcibíades fez centenas de anos atrás? Ou seja, pensava o filósofo, para que alguém pudesse cuidar dos outros, é necessário esse alguém primeiro cuidar de si. (PLATÃO, 1977).

Os discursos político-religiosos do Estado, Nelson e Igreja "sempre" estiveram ligados à reelaboração, a qual possuía como base apreensões de cunho privado (quer-se dizer inerentes ao próprio discurso), mas também as provenientes da coletividade. Nesta esteira, as preocupações do em torno de si (do discurso em sua matriz) se ligavam abertamente às "necessidades" dos outros. O aprofundamento das pesquisas demonstrou que, na medida em que a formulação do discurso colocava a persuasão como instrumento trivial, ele transformase por natureza em domínio variante. De maneira literal, o discurso é uma teia que envolve, por exemplo, a palavra escrita, a voz, os gestos, as fisionomias, o convencimento, tais fatores o expõe nos interstícios de redes absolutamente extensas e [pretendidas] coesas, mas ao mesmo tempo flexíveis conforme a intenção de cada remetente e, de forma óbvia, as bases de necessidade de cada destinatário sempre estiveram em pauta. $\mathrm{Na}$ ausência de melhores palavras, aqui emprega-se o entendimento de que o discurso sofre variações conforme o tempo e o espaço em que é elaborado e aplicado, assim sendo, desta sentença as pessoas e instituições em tela jamais estiveram livres, visto que se movimentavam no tempo e no espaço aquando da formulação e da aplicabilidade das suas ideias. 


\section{REFERÊNCIAS BIBLIOGRÁFICAS}

CAMPOS, Ipojucan Dias. Para além da tradição: casamentos, famílias e relações conjugais (Belém, 1916-1940). São Paulo: Fonte Editorial, 2016.

CAMPOS, Ipojucan Dias. Casamento, divórcio e meretrício em Belém no final do século XIX (1890-1900). Dissertação apresentada no Programa de História Social da Pontifícia Universidade Católica de São Paulo PUC-SP. São Paulo: Mimeo, 2004.

FEBVRE, Lucien. História. São Paulo: Ática, 1978.

LEFEBVRE, George. La naissance de l'historiographie moderne. Paris: Flammarion, 1971.

LE GOFF, Jacques. História e memória. São Paulo: Editora da UNICAMP, 1996.

PLATÃO. Diálogos: Timeu, críticas, o $2^{\circ}$ Alcibíades e hípias menor. Belém: Editora da Universidade Federal do Pará, 1977.

ZUMTHOR, Paul. A letra e a voz: a literatura medieval. São Paulo: Companhia das Letras, 1993.

ZUMTHOR, Paul. Document et monument. A propos des plus anciens textes de langue française. In: Revue des sciences humaines. Paris, vol. 97, p. 05-19.

\section{DOCUMENTOS}

A República. Belém, 01 de abril de 1890, p. 02.

A República. Belém, 01 de julho de 1890, p. 01.

A República. Belém, 15 de julho de 1890, p. 01

A Semana Religiosa. Belém, 10 de fevereiro de 1890, p. 01.

Decretos do Governo Provisório da República dos Estados Unidos do Brasil de 1890. Sexto fascículo de 1 a 30 de junho de 1890. Rio de Janeiro: Typ. da Imprensa Nacional, 1890.

Decreto 119 A, de 07 de janeiro de 1890. Decretos do Governo Provisório da República dos Estados Unidos do Brasil de 1890.

O Apologista Cristão Brasileiro. Belém, 15 de fevereiro de 1890, p. 01.

O Apologista Cristão Brasileiro. Belém, 22 de fevereiro de 1890, p. 02.

O Apologista Cristão Brasileiro. Belém, 01 de março de 1890, p. 02.

O Apologista Cristão Brasileiro. Belém, 24 de maio de 1890, p. 02.

O Apologista Cristão Brasileiro. Belém, 21 de junho de 1890, p. 02.

O Apologista Christão Brasileiro. Belém, 01 de outubro de 1892, p. 02.

Semana Religiosa do Pará. Belém, 23 de março de 1890, p. 182. 